\title{
Recent Decadal Trend in the North Atlantic Wind Energy Resources
}

\author{
Chong Wei Zheng, ${ }^{1,2,3}$ Chong Yin $\mathrm{Li}^{1,2}$ and $\mathrm{Xin} \mathrm{Li}^{1}$ \\ ${ }^{1}$ College of Meteorology and Oceanography, People's Liberation Army University of Science and Technology, Nanjing 211101, China \\ ${ }^{2}$ National Key Laboratory of Numerical Modeling for Atmospheric Sciences and Geophysical Fluid Dynamics (LASG), \\ Institute of Atmospheric Physics, The Chinese Academy of Sciences, Beijing 100029, China \\ ${ }^{3}$ Dalian Naval Academy, Dalian 116018, China
}

Correspondence should be addressed to Chong Wei Zheng; chinaoceanzcw@sina.cn

Received 15 May 2016; Revised 22 August 2016; Accepted 19 October 2016; Published 9 January 2017

Academic Editor: George Xydis

Copyright (C) 2017 Chong Wei Zheng et al. This is an open access article distributed under the Creative Commons Attribution License, which permits unrestricted use, distribution, and reproduction in any medium, provided the original work is properly cited.

\begin{abstract}
This study presents the climatic trend of the North Atlantic wind energy using cross-calibrated, multiplatform (CCMP) wind data for the period 1988-2011. Results show the following. (1) The North Atlantic WPD exhibited a significant increasing trend of 4.45 $\left(\mathrm{W} / \mathrm{m}^{2}\right) / \mathrm{yr}$ over the past 24 years. (2) The variation in the North Atlantic Ocean WPD shows a noticeable regional difference. More than half of the North Atlantic Ocean has a significantly increasing trend in WPD. The increasing trend in the mid-high latitudes is stronger than that in the low latitudes, and the trend is stronger in the west than in the east. The area with the strongest increasing trend is located along the southern coast of Greenland of $35\left(\mathrm{~W} / \mathrm{m}^{2}\right) / \mathrm{yr}$. (3) There is a noticeable seasonal difference in the variation of WPD. The strongest increasing trend occurs in December-January-February (DJF), followed by September-October-November (SON) and March-April-May (MAM), and the weakest occurs in June-July-August (JJA). The increasing trend in different areas is dominated by different seasons. (4) There is no leading or lagging correlation between WPD and the North Atlantic Oscillation (NAO). However, there is a noticeable negative correlation between the Niño3 index and WPD in most of the North Atlantic.
\end{abstract}

\section{Introduction}

With the negative effects of the resource crisis increasing, many countries are forced to investigate environmentally friendly, renewable, and sustainable energy. Power supply issues have often restricted the economic development of coastal cities and isolated islands. Many countries advocate for the application of renewable energy. Global investments in renewable power and fuel increased to a new record of $\$ 285.9$ billion in 2015, the first increase in four years with the largest investments in the wind and solar energy sectors [13]. Wind energy is the most advanced of the "new" renewable power technologies and has been the largest single sector for investment in recent years [4]. Wind energy is also believed to have the lowest adverse environmental impacts [5] and is competitive in cost to other fuel sources $[3,6-8]$. The full development and utilization of offshore wind energy will be beneficial to the sustainable development of human society and isolated islands.

In the development of wind power, it is necessary to analyze the characteristic and rich degree of wind energy resource. In 2008, the National Aeronautics and Space Administration [9] and Liu et al. [10] created global ocean wind power density (WPD) contours. These results show that the energy-rich areas are mainly located in western belts of the Northern $\left(500-1000 \mathrm{~W} / \mathrm{m}^{2}\right)$ and Southern Hemispheres $\left(800-1600 \mathrm{~W} / \mathrm{m}^{2}\right)$. Archer and Jacobson [11] quantified the world's wind power potential and concluded that the power generated at locations with mean annual wind speeds $\geq$ $6.9 \mathrm{~m} / \mathrm{s}$ at $80 \mathrm{~m}$ is $\sim 72 \mathrm{TW}(\sim 54000$ Mtoe). If only $25 \%$ of this power could be captured, it could satisfy the world's main energy demands in 2015 (4200 Mtoe oil, 3900 Mtoe coal, 3200 Mtoe natural gas, and 300 Mtoe renewable energy in power, [12]). Using temporal and spatial distributions of 


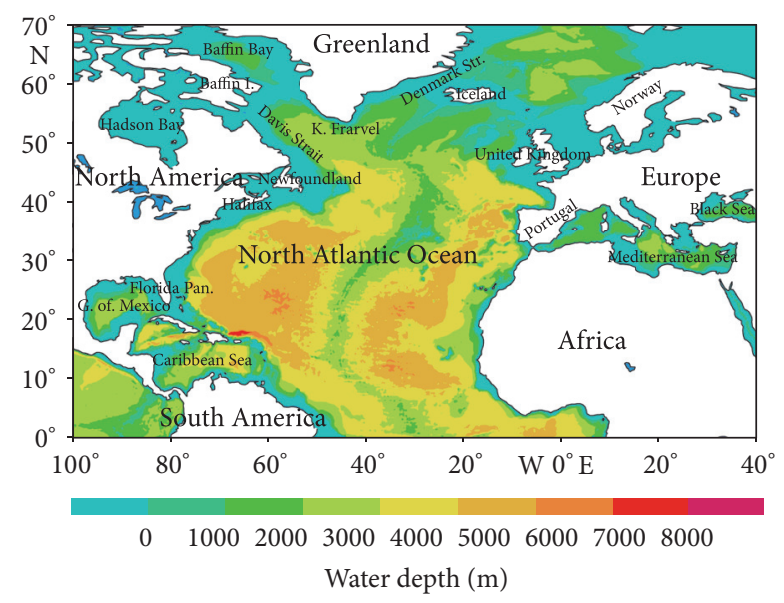

Figure 1: Topography of the North Atlantic.

WPD, wind energy levels, and effective wind speed, as well as considering wind energy storage and the stability and longterm trends of WPD, Zheng and Pan [13] attempted to classify the global ocean wind energy resource. They concluded that the global ocean is rich in wind energy, especially in the winter Hemisphere.

Many excellent contributions to wind energy resource assessments have been provided by previous researchers. Until now, there has been little research regarding the longterm trend of wind energy, which is one of the most important points to consider in wind power plant selection. An increasing trend in WPD is helpful for the development of the wind energy resource, while the opposite is not conducive to longterm development and utilization. This study calculates the climatic trend of the wind energy in the North Atlantic, based on the cross-calibrated, multiplatform (CCMP) wind data for the period 1988-2011, in the hope of providing a reference for the long-term plan of wind energy development.

\section{Data and Methodology}

The WPD is obtained from the CCMP wind data, calculated as follows:

$$
W=\frac{1}{2} \rho V^{3}
$$

where $W$ is the WPD $\left(\mathrm{W} / \mathrm{m}^{2}\right), V$ is the wind speed at $10 \mathrm{~m}$ above surface $(\mathrm{m} / \mathrm{s})$, and $\rho$ is the standard sea-level air density $\left(1.225 \mathrm{~kg} / \mathrm{m}^{3}\right)$ [14]. Combining expression (1) with the CCMP wind data, we obtained the 6-hourly North Atlantic WPD of $10 \mathrm{~m}$ above the sea surface for the period 1988-2011. The topography characteristic is shown in Figure 1.

The CCMP ocean surface wind product is hosted at the Physical Oceanography Distributed Active Archive Center (PO.DAAC) and has been evaluated and utilized extensively by the science community $[15,16]$. The data is derived through cross-calibration and assimilation of ocean surface wind data from Special Sensor Microwave Imager (SSM/I), Tropical Rainfall Measuring Mission (TRMM), Microwave

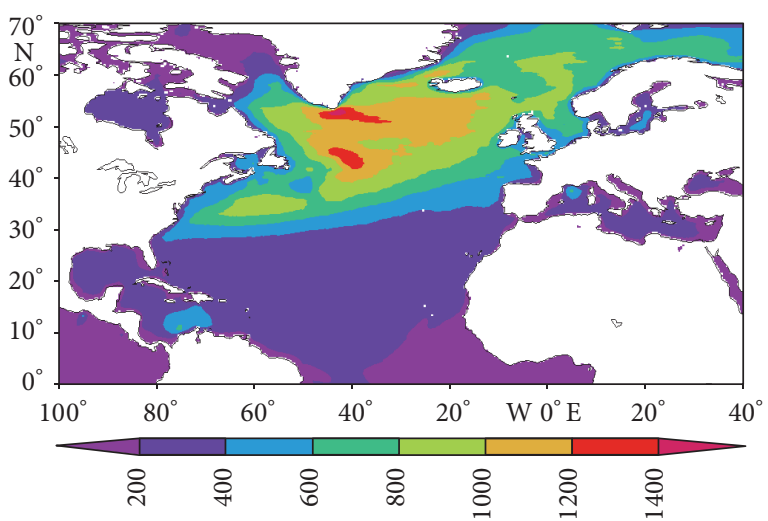

FIGURE 2: Annual average wind power density in the North Atlantic, unit: $\mathrm{W} / \mathrm{m}^{2}$

Imager (TMI), Advanced Microwave Scanning RadiometerEarth Observing System (AMSR-E), SeaWinds on Quick Scatterometer (QuikSCAT), and SeaWinds on Advanced Earth Observing Satellite 2 (ADEOS-II). Cross-calibration is performed by Remote Sensing Systems (RSS) under the Distributed Information Services for Climate and Ocean Products and Visualizations for Earth Research (DISCOVER) Project. These data sets are combined with conventional observations and a starting estimate of the wind field using a variational analysis method (VAM). The VAM requires a background (or first guess) analysis of gridded $\mathrm{u}$ and $\mathrm{v}$ wind components as a prior estimate of the wind field. The $40-\mathrm{yr}$ ECMWF Re-Analysis (ERA-40) is used as the background for the period July 1987 to December 1998. Beginning in 1999, with the benefits of four-dimensional variational data assimilation (4DVAR) and increased spatial resolution, the ECMWF operational (ECOP) analysis outperforms the ERA40 and is used here for the background. Its time resolution is 6 hours, and the spatial resolution is $0.25^{\circ} \times 0.25^{\circ}$, with the time range from July 1987 to December 2011 and space range is $78.375^{\circ} \mathrm{S} \sim 78.375^{\circ} \mathrm{N}, 0.125^{\circ} \sim 379.875^{\circ} \mathrm{E}$. The CCMP wind data is widely used in the evaluation of wind energy resource $[13,17]$.

\section{Climatic Trend of Wind Power Density}

3.1. Distribution Characteristic of Wind Power Density. The average WPD in the North Atlantic was calculated by averaging the WPD at each $0.25^{\circ} \times 0.25^{\circ}$ bin from 0000 UTC on January 1, 1988, to 1800 UTC on December 31, 2011 (Figure 2). The North Atlantic is rich in wind energy resources as a whole. Under the influence of strong westerly winds, the largest area of high WPD is distributed between $40^{\circ} \mathrm{N}$ and $60^{\circ} \mathrm{N}$, with the maximum value appearing south of Greenland, where average values are over $1000 \mathrm{~W} / \mathrm{m}^{2}$ and reach greater than $1400 \mathrm{~W} / \mathrm{m}^{2}$ in the center. WPD is greater than $600 \mathrm{~W} / \mathrm{m}^{2}$ north of $30^{\circ} \mathrm{N}$ and ranges from 200 to $400 \mathrm{~W} / \mathrm{m}^{2}$ between $10^{\circ} \mathrm{N}$ and $30^{\circ} \mathrm{N}$. The wind energy is relatively poor in Baffin Bay $\left(<200 \mathrm{~W} / \mathrm{m}^{2}\right)$, Hudson Bay $\left(200-400 \mathrm{~W} / \mathrm{m}^{2}\right)$, and the Mediterranean Sea $\left(<400 \mathrm{~W} / \mathrm{m}^{2}\right)$. Under the impact of 


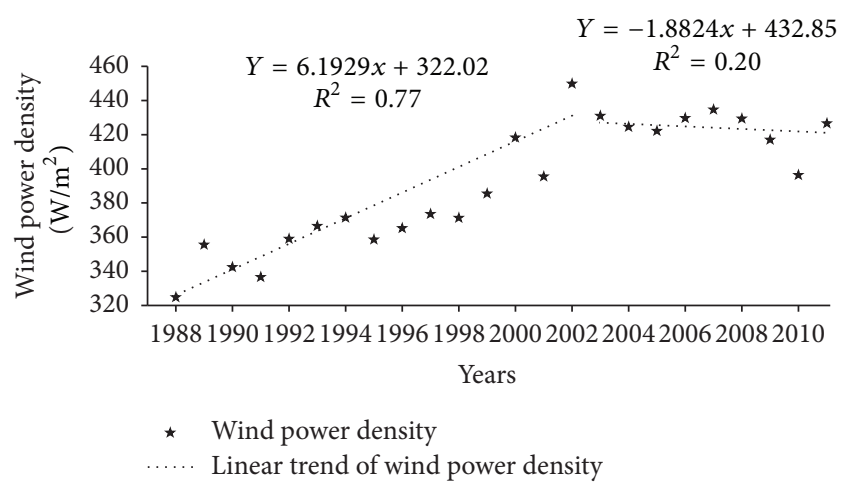

FIgURE 3: Annual average wind power density and its long-term trend in the North Atlantic.

the equatorial doldrums, the equatorial waters are also poor in wind energy, with average values below $200 \mathrm{~W} / \mathrm{m}^{2}$.

As shown in Figure 2, the WPD in the mid and high latitudes of the North Atlantic is greater than $400 \mathrm{~W} / \mathrm{m}^{2}$ (with some areas greater than $1200 \mathrm{~W} / \mathrm{m}^{2}$ ), which is only slightly lower than the values estimated by Liu et al. (greater than $500 \mathrm{~W} / \mathrm{m}^{2},[10]$ ) in this same region. Our results are also consistent with the conclusions reported by NASA [9] and Capps and Zender [14]. Using 1000 satellite Synthetic Aperture Radar (SAR) images, Hasager et al. [18] concluded that WPD ranged from 300 to $800 \mathrm{~W} / \mathrm{m}^{2}$ at the 14 existing and 42 planned wind farms in the Baltic Sea. The study also concluded that the highest WPD value is located in the Skagerrak Strait, not in the Baltic Sea. Our calculated average in the Baltic Sea $\left(200-600 \mathrm{~W} / \mathrm{m}^{2}\right)$ is smaller than the result reported by Hasager et al. [18]. Through statistical analyses of $10 \mathrm{~m}$ National Centers for Environmental Prediction/Department of Energy (NCEP/DOE) wind data for the period 1979-2010, Chadee and Clarke [19] found that the Caribbean low-level jet (CLLJ) region is an area of superb WPD (400-600 W/ $\left./ \mathrm{m}^{2}\right)$; the eastern Caribbean and the Netherland Antilles are locations of excellent WPD (300$\left.400 \mathrm{~W} / \mathrm{m}^{2}\right)$; and the Greater Antilles and the Bahamas are areas of good to very good WPD $\left(200-300 \mathrm{~W} / \mathrm{m}^{2}\right)$. It is clear that there is consistency between our results and Chadee and Clarke's [19] results in the Caribbean region. Capps and Zender [20] estimated that $80 \mathrm{~m}$ wind power is $1.2-1.5$ times greater than $10 \mathrm{~m}$ wind power between the equator and $30^{\circ}$ latitude; $1.4-1.7$ times greater than $10 \mathrm{~m}$ wind power in the winter storm track regions; and more than 6 times greater than $10 \mathrm{~m}$ wind power in the stable regions east of the continents. This implies that the $80 \mathrm{~m}$ wind power in the North Atlantic is much greater than the $10 \mathrm{~m}$ wind power shown in Figure 2.

3.2. Overall Trend of Wind Power Density. The average annual values of WPD were calculated using the zonal average of WPD from 0000 UTC on January 1 to 1800 UTC on December 31 for each year from 1988 to 2011 . The overall trend of the North Atlantic WPD for 1988-2011 was analyzed using a linear regression, as shown in Figure 3.

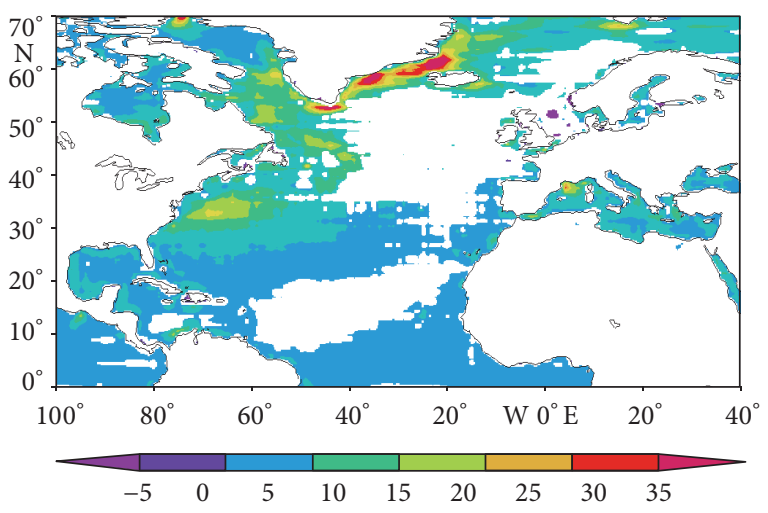

FIGURE 4: Long-term annual trend of wind power density in the North Atlantic, unit: $\left(\mathrm{W} / \mathrm{m}^{2}\right) / \mathrm{yr}$. Only areas significant at the $95 \%$ level are presented.

Over the whole period of 1988-2011, the relationship coefficient $\left(R^{2}=0.76,|R|=0.87>r_{0.001}=0.60\right)$ is significant at the $99.9 \%$ level. The regression coefficient is 4.45, indicating that the North Atlantic as a whole exhibited a significant increasing trend in WPD of $4.45\left(\mathrm{~W} / \mathrm{m}^{2}\right) / \mathrm{yr}$ over the 24 years analyzed in this study. Young et al. [21] also found a general global trend of increasing wind speed values for the period 1991-2008, agreeing with the results of our study. We found that the highest WPD values occurred in 2002. Based on this peak, we divided the time series into two periods: 1988-2002 and 2003-2011. The long-term trends of WPD for each period were calculated separately, as shown in Figure 3. For the period 1988-2002, the relationship coefficient $\left(R^{2}=\right.$ $\left.0.77,|R|=0.88>r_{0.001}=0.73\right)$ is significant at the $99.9 \%$ level. The regression coefficient is 6.19 , meaning that the North Atlantic WPD exhibited a significant increasing trend of $6.19\left(\mathrm{~W} / \mathrm{m}^{2}\right) / \mathrm{yr}$ over the period $1988-2002$. For the period of 2003-2011, the relationship coefficient $\left(R^{2}=0.20\right.$, $\left.|R|=0.45<r_{0.1}=0.52\right)$ is not significant at the $90 \%$ reliability level, meaning that the North Atlantic WPD does not vary significantly over the period of 2003-2011. Instead, the WPD changes gradually over this time period. The year 2010 is anomalous in terms of WPD, with the lowest values of the 2003-2011 period. There is strong agreement between our results in Figure 3 and the results of Earl et al. [22], who also found that 2010 was an anomalously low wind year and was therefore a relatively bad year for wind energy production but a good year for the insurance industry in terms of reduced claim volume.

3.3. Regional Differences of the Long-Term Trend in Wind Power Density. The annual mean WPD in the North Atlantic was calculated by averaging the WPD from 0000 UTC on January 1 to 1800 UTC on December 31 at each $0.25^{\circ} \times 0.25^{\circ}$ bin for each year from 1988 to 2011. The long-term trend of the North Atlantic WPD at each $0.25^{\circ} \times 0.25^{\circ}$ bin from 1988 to 2011 was analyzed using a linear regression, as shown in Figure 4 .

More than half of the North Atlantic exhibits a significant increasing trend in WPD, a phenomenon that is a benefit for the development of the wind energy resource. The increasing 


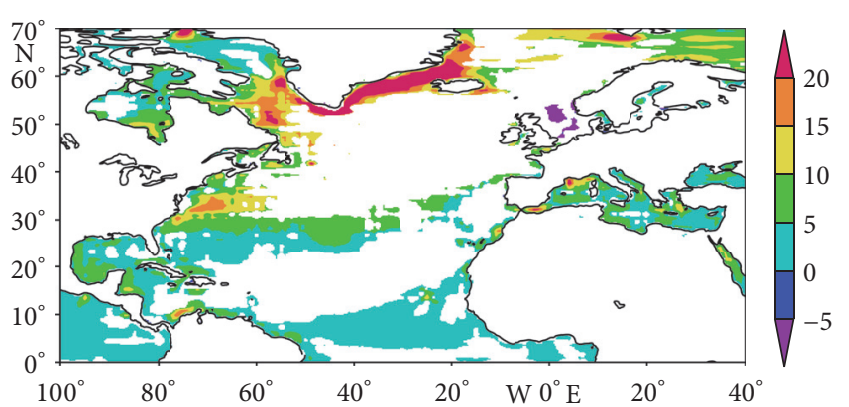

(a)

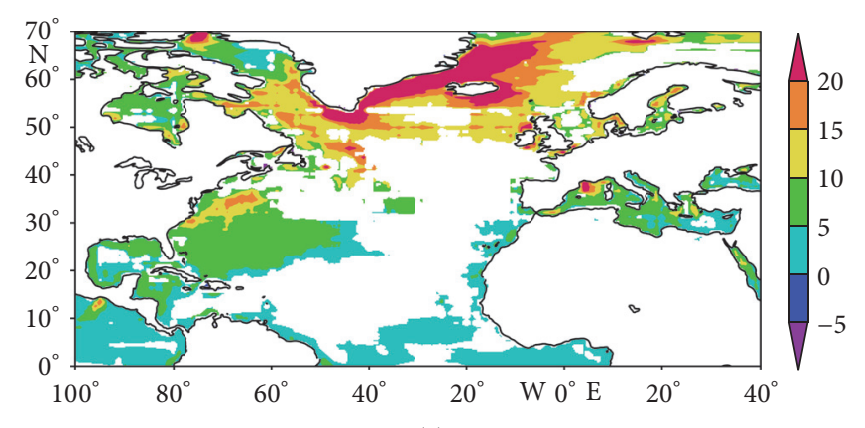

(c)

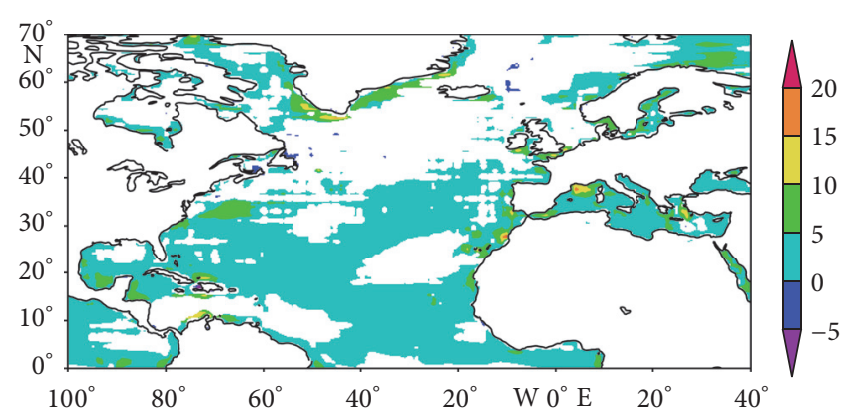

(b)

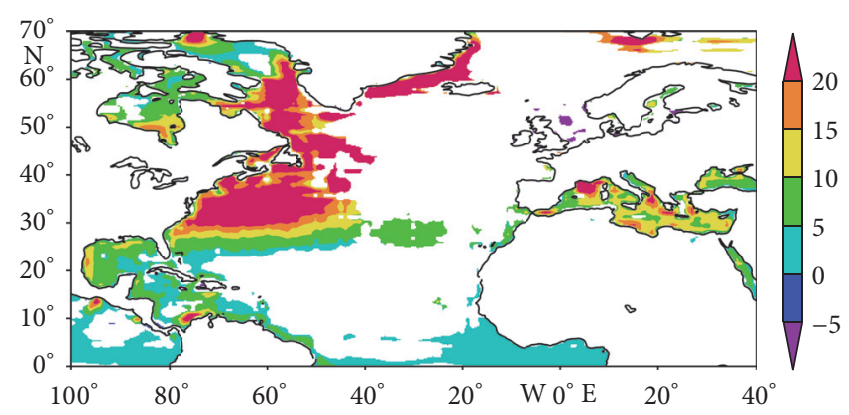

(d)

FIGURE 5: Long-term trends of the wind power density in MAM (a), JJA (b), SON (c), and DJF (d), unit: (W/m²)/yr. Only areas significant at the $95 \%$ level are presented.

trend in the mid and high latitudes is stronger than the trend in the lower latitudes. Additionally, the increasing trend in the west is stronger than that in the east. The areas with the strongest increasing trends in WPD are located in the waters south of Greenland, surrounding Hamilton, and in the northern portion of Baffin Bay, where WPD values are increasing at rates over $15\left(\mathrm{~W} / \mathrm{m}^{2}\right) / \mathrm{yr}$; in the south coastal waters of Greenland in particular, the increasing trend can even be up to $35\left(\mathrm{~W} / \mathrm{m}^{2}\right) / \mathrm{yr}$. The WPD in the low latitudes is increasing at rates at or below $10\left(\mathrm{~W} / \mathrm{m}^{2}\right) / \mathrm{yr}$. The regions south of Iceland and a belt around $10^{\circ} \mathrm{N}$ do not show a significant variation in WPD. Only isolated regions of water, such as some small areas in the North Sea, have significant decreasing trends.

Earl et al. [22] found little variation in WPD in the UK for the period 1980-2010 (approximately $-3\left(\mathrm{~W} / \mathrm{m}^{2}\right) / \mathrm{yr}$ ) using data from a 40-station wind monitoring network. Our results in the UK are consistent with the results of Earl et al. [22]. As shown in Formula (1), the primary driver of variation in WPD is wind speed. Young et al. [21] presented a general global trend of increasing wind speeds over the period 1991-2008, utilizing an 18-year database of calibrated and validated satellite altimeter measurements. Thomas et al. [23] determined that trends remain in the annual means of spatially averaged and adjusted wind data, with estimated rates of $40 \mathrm{~cm} / \mathrm{s} /$ decade $\left(6 \%\right.$ decade $\left.^{-1}\right)$ and measured rates of $20 \mathrm{~cm} / \mathrm{s} /$ decade $\left(3 \%\right.$ decade $\left.^{-1}\right)$ in most of the global ocean between 1982 and 2002. Additionally, Sušelj et al. [24] found a positive trend in the North Sea $10 \mathrm{~m}$ wind speed for the period 1980-2000. Finally, Bertin et al. [25] found an increase in significant wave height (SWH) in the Atlantic Ocean north of $50^{\circ} \mathrm{N}$ after accounting for interannual variability, with rates reaching $1 \mathrm{~cm} / \mathrm{yr}$ (a $20-40 \%$ increase over the 20 th century). This increase in SWH is explained by a more than $20 \%$ increase in wind speed in areas north of $50^{\circ} \mathrm{N}$. The increasing trend of wind speed north of $50^{\circ} \mathrm{N}$ in the North Atlantic is consistent with our results. It is clear that our results have good agreement with previous research.

3.4. Seasonal Differences of the Long-Term Trend in Wind Power Density. To show the seasonal differences in the long-term variation in the North Atlantic WPD, we calculated the variation in WPD for the periods March-AprilMay (MAM), June-July-August (JJA), September-OctoberNovember (SON), and December-January-February (DJF) for 1988-2011, as shown in Figure 5. There is a noticeable seasonal difference in the long-term trend of the North Atlantic WPD. The strongest increasing trend occurs in DJF, followed by SON and MAM. The increasing trend was the smallest in JJA.

In MAM, the waters around $10^{\circ} \sim 20^{\circ} \mathrm{N}$ and $30^{\circ} \sim 50^{\circ} \mathrm{N}$ do not exhibit significant variations in WPD. The waters with the strongest increasing trend are primarily distributed near the coast of Greenland and along the Davis Strait, where rates reach over $20\left(\mathrm{~W} / \mathrm{m}^{2}\right) / \mathrm{yr}$. The waters along the east coast of North America exhibit a relatively strong increase in WPD, approximately $10-20\left(\mathrm{~W} / \mathrm{m}^{2}\right) / \mathrm{yr}$.

In JJA, the increasing trend in WPD is the smallest throughout the year. The high-latitude waters do not exhibit significant variations. The waters with significant increasing 


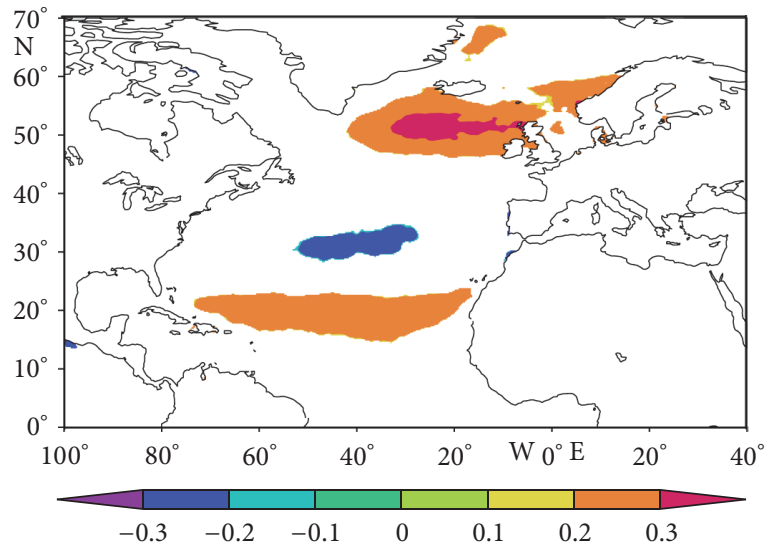

(a)

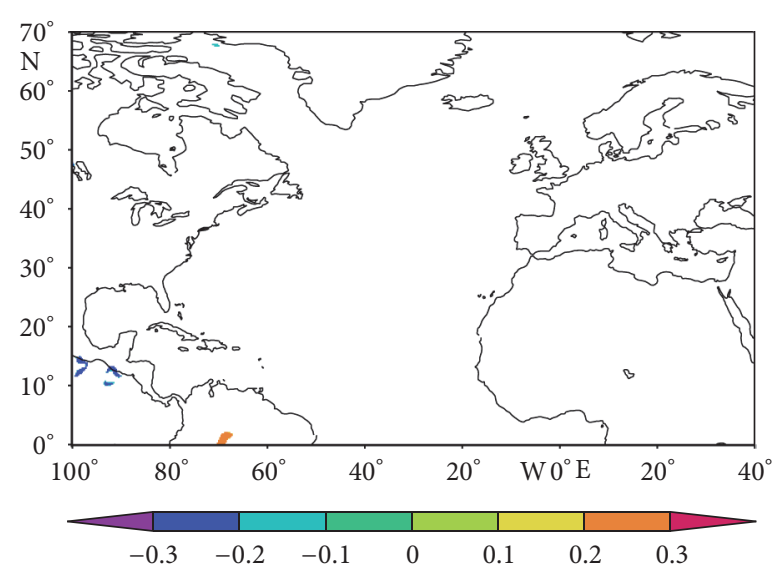

(b)

Figure 6: Correlation between wind power density and NAO. (a) Contemporaneous correlation; (b) correlation between the NAO index and wind power density (lagging 2 months). Only areas significant at the $95 \%$ level are shown.

trends are mainly located in the mid to low latitude regions, where the rates are approximately $0-5\left(\mathrm{~W} / \mathrm{m}^{2}\right) / \mathrm{yr}$.

In SON, the waters surrounding Greenland and Iceland, the waters along the east coast of North America, the Gulf of Mexico, and the Mediterranean Sea all exhibit a significant increasing trend in WPD, with the highest trend located in the waters surrounding Greenland and Iceland (over $20\left(\mathrm{~W} / \mathrm{m}^{2}\right) / \mathrm{yr}$ ). Waters in the center of the mid to low latitudes of the Atlantic Ocean did not vary significantly over the past 24 years.

In DJF, the increasing trends in WPD in waters surrounding Greenland, the Davis Strait, waters along the east coast of North America, the Gulf of Mexico, and the Caribbean and Mediterranean Seas are the strongest of the entire year. The largest areas are mainly distributed in waters surrounding Greenland and the waters along the east coast of North America, where the trends increase at rates over $20\left(\mathrm{~W} / \mathrm{m}^{2}\right) / \mathrm{yr}$.

When comparing the variations in Figures 4 and 5, it is clear that the increasing trend in the North Atlantic WPD is dominated by the increasing trend that occurs in DJF. The variations in WPD in different regions are dominated by different seasons. The increasing trends in the Davis Strait and along the east coast of North America are mainly dominated by the trends that occur in DJF, followed by the trends in MAM and SON. The increasing trend in the waters surrounding Greenland is dominated by the trend that occurs in SON, followed by the trends in MAM and DJF. The increasing trends in the low latitude waters are mainly dominated by the trend that occurs in JJA.

\section{Discussion}

4.1. Correlation between the NAO and Wind Power Density. Studies by Young et al. [21], Gulev and Grigorieva [26], and Bertin et al. [25] provided evidence for the longterm variation in SWH after correction for interannual variability controlled by oscillating phenomena, such as the
North Atlantic Oscillation (NAO) and the El Niño Southern Oscillation (ENSO). The NAO is a weather phenomenon in the North Atlantic Ocean that is a result of fluctuations in atmospheric pressure at sea level between the Icelandic low pressure and the Azores high pressure areas. Influenced by the fluctuations in the strengths of the Icelandic low and the Azores high, the NAO controls the strength and direction of westerly winds and storm tracks across the North Atlantic Ocean [27]. Dodet et al. [28] found a strong positive correlation between SWH and the NAO index in northern latitudes. Ocean waves are locally generated by the wind [29], meaning that there is also a close relationship between the $\mathrm{NAO}$ and wind. Zhai and Wunsch [30] found a correlation between the winter NAO index and winter WPD in the North Atlantic. Hurrell [31] concluded that winter storms in the North Atlantic are driven by the strength of the westerly winds, which can be deduced from the NAO index. Sušelj et al. [24] found that the dominant mode of the North Sea $10 \mathrm{~m}$ wind speed (WS10) explains the variability of WS10 over the North Sea and is related to a sea-level pressure (SLP) pattern similar to the NAO. Reguero et al. [32] analyzed the monthly correlations between wave energy and several climate indices (e.g., the Atlantic Multidecadal Oscillation (AMO); the Arctic Oscillation (AO); the East Atlantic oscillation (EAO); the $\mathrm{NAO}$; the Pacific-North America Index (PNA); and the Southern Hemisphere Annular Mode (SAM)). Their results show that there is a close relationship between the NAO and wave power density. Following their method, the monthly correlation between WPD and climate indices (NAO, Niño3 index) was calculated.

The NAO index is commonly defined as the difference in the normalized pressure between a station in the Azores and a station in Iceland. The NAO has a particularly dominant effect on the climate in winter months. In general, a positive NAO index is associated with windier, warmer, and wetter winters in northern Europe, while a negative NAO index is associated with less windy, colder, and drier winters in the area. In this study, we calculate the correlation between WPD and the NAO index, as shown in Figure 6. An ellipse-shaped 


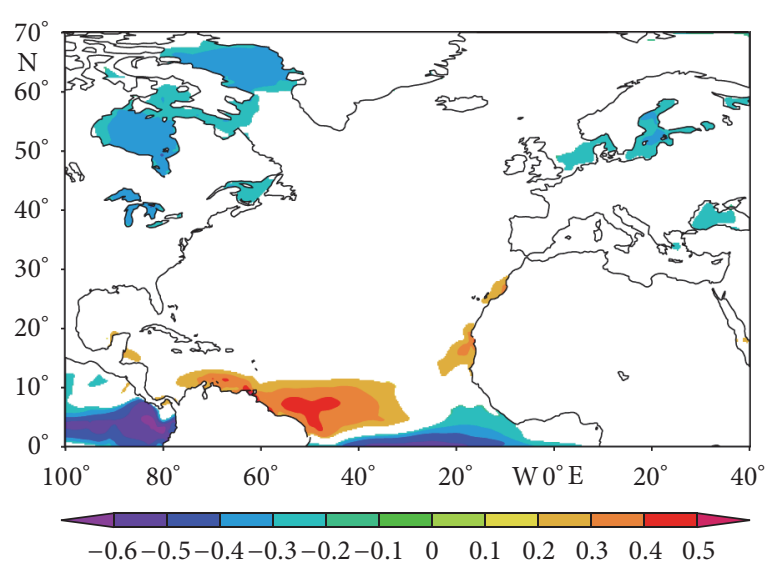

(a)

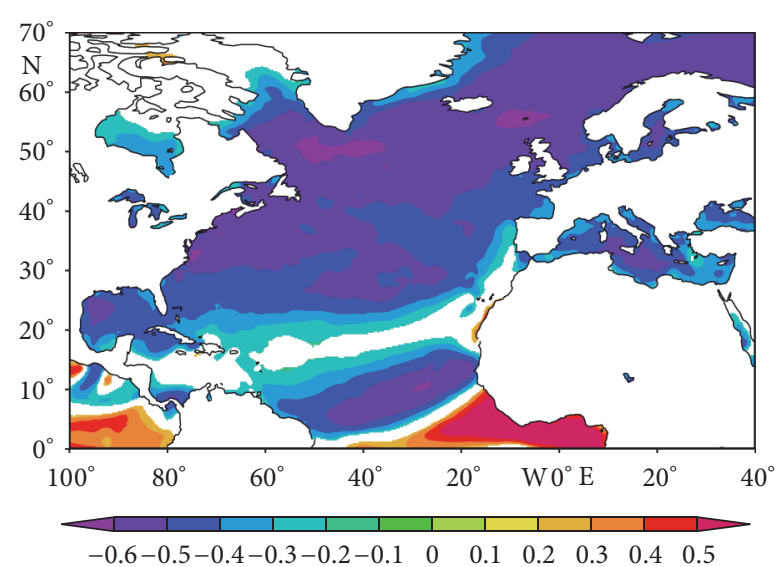

(b)

Figure 7: Correlation between wind power density and the Niño3 index. (a) Contemporaneous correlation; (b) correlation between the Niño3 index and wind power density (lagging 3 months). Only areas significant at the $95 \%$ level are shown.

area south of Iceland and an east-west belt near $20^{\circ} \mathrm{N}$ exhibit significant positive correlations between WPD and the NAO index. Only a small area near $30^{\circ} \mathrm{N}$ exhibits a noticeable negative correlation between WPD and the NAO index. WPD in most of the North Atlantic is not significantly correlated with the NAO index. In addition, there is not a leading or lagging correlation between WPD and the NAO index.

4.2. Correlation between ENSO and Wind Power Density. We also calculated the correlation between WPD and the Niño3 index, as shown in Figure 7. The Niño3 index is defined as the mean monthly temperature anomaly in the eastern tropical Pacific: $5^{\circ} \mathrm{S}-5^{\circ} \mathrm{N}, 150^{\circ} \mathrm{W}-90^{\circ} \mathrm{W}$ [33]. Overall, WPD in most of the North Atlantic is not significantly correlated with the Niño3 index, as shown in Figure 7(a). A small area east of South America shows a noticeable positive correlation between WPD and the Niño3 index, while waters near the equator, Baffin Bay, and Hudson Bay exhibit significant negative correlations. As shown in Figure 7(b), we find a very strong negative correlation between the Niño3 index and WPD (lagging 3 months) in most of the North Atlantic. This correlation is stronger in the mid and high-latitude waters than in the low latitude waters. The only area that does not display a significant correlation between the Niño3 index and WPD is a small belt near $15^{\circ} \mathrm{N}$ (lagging 3 months). Waters in the eastern equatorial region of the North Atlantic exhibit a noticeable positive correlation between the Niño3 index and WPD (lagging 3 months). In conclusion, there is a noticeable negative correlation between the ENSO and WPD (lagging 3 months) in the North Atlantic, which can be attributed to the Niño3 index. The Niño3 index is always highest in the winter; therefore, the 3-month lagging period will always exhibit a negative correlation because wind speed in the spring is lower than that in the winter. Zheng et al. [34] found a significant increase in occurrences of wind speeds greater than Class 5. They also noted that this phenomenon has a close relationship with the ENSO. Wan [35] noted that meteorological interannual oscillations, such as the ENSO, could contribute to the wind power interannual variations observed in the available data over the period 2000-2010. Liu et al. [10] identified alternating high and low WPD caused by wind-stress modification of sea surface temperature (SST) along the semipermanent meanders of the mid latitude currents, such as the Agulhas Extension [36], the Kuroshio Extension, and the Gulf Stream. As a result, it is possible to make a mid- to long-term prediction of the wind energy based on the correlation between the ENSO and WPD to assist the mid- to long-term development of wind energy and improve the absorption and conversion of wind energy resources.

\section{Conclusions}

The present study analyzed the long-term trend of the wind energy in the North Atlantic, based on CCMP wind data for the period 1988-2011. The overall trends, regional differences, and seasonal differences in the long-term trends are identified. The correlation between the NAO and WPD, as well as the correlation between the ENSO and WPD, is also calculated, in the hope of providing guidance for long-term wind energy development. The results show the following:

(1) The North Atlantic is rich in wind energy resources as a whole. The largest area of WPD is mainly distributed between $40^{\circ} \mathrm{N}$ and $60^{\circ} \mathrm{N}$, with the maximum WPD appearing in the waters south of Greenland with values of $1000 \mathrm{~W} / \mathrm{m}^{2}$ to greater than $1400 \mathrm{~W} / \mathrm{m}^{2}$ in the center. WPD is approximately $600 \mathrm{~W} / \mathrm{m}^{2}$ north of $30^{\circ} \mathrm{N}$ and $200-400 \mathrm{~W} / \mathrm{m}^{2}$ in the waters between $10^{\circ} \mathrm{N}$ and $30^{\circ} \mathrm{N}$. The equatorial region has low WPD with values below $200 \mathrm{~W} / \mathrm{m}^{2}$.

(2) The North Atlantic WPD exhibits a significant increasing trend of $4.45\left(\mathrm{~W} / \mathrm{m}^{2}\right) / \mathrm{yr}$ in the North Atlantic as a whole for the period 1988-2011. Over the period of 1988-2002, the increasing trend of WPD approached $6.1929\left(\mathrm{~W} / \mathrm{m}^{2}\right) / \mathrm{yr}$. Over the period of 
2003-2011, the WPD changed gradually and did not exhibit a significant variation.

(3) The variation in WPD in the North Atlantic exhibits a noticeable regional difference. More than half of the North Atlantic has a significantly increasing trend in WPD. The increasing trend in the mid and high latitudes is stronger than the trend in the low latitude waters, while the trend in the western waters is stronger than the trend in the eastern waters. Areas with a strong increasing trend in WPD are mainly distributed south of Greenland, in waters surrounding Hamilton, and in the northern portion of Baffin Bay, where WPD increases at rates above $15\left(\mathrm{~W} / \mathrm{m}^{2}\right) / \mathrm{yr}$. The waters south of Greenland display the largest trends, where WPD increases at a rate of $35\left(\mathrm{~W} / \mathrm{m}^{2}\right) / \mathrm{yr}$.

(4) There is a noticeable seasonal difference in the longterm trend of the North Atlantic WPD. The strongest increase occurs in DJF, followed by SON and MAM. The increasing trend in JJA is the smallest of the year. The increasing trends in the Davis Strait and the waters along the east coast of North America are mainly dominated by the trends occurring in DJF, while the trend occurring in SON dominates the increasing trend in the waters surrounding Greenland. The increasing trend in low latitude waters is mainly dominated by the trend occurring in JJA.

(5) WPD in most of the North Atlantic does not have a significant contemporaneous correlation with the NAO. An ellipse-shaped area south of Iceland and an east-west belt near $20^{\circ} \mathrm{N}$ exhibit significant positive correlations between WPD and the NAO. Only a small region near $30^{\circ} \mathrm{N}$ exhibits a noticeable negative correlation between WPD and the NAO. In addition, there are no leading or lagging correlations between WPD and the NAO. As a whole, WPD in the North Atlantic does not have significant contemporaneous correlation with the Niño3 index. However, there is a noticeable strong negative correlation between the ENSO and WPD (lagging 3 months) in most portions of the North Atlantic.

\section{Glossary}

4DVAR: $\quad$ Four-dimensional variational data assimilation

ADEOS-II: Advanced Earth Observing Satellite 2

AMSR-E: Advanced Microwave Scanning Radiometer-Earth Observing System

CCMP: Cross-calibrated, Multiplatform

CLLJ: Caribbean low-level jet

DISCOVER: Distributed Information Services for Climate and Ocean Products and Visualizations for Earth Research

DJF: $\quad$ December-January-February

ECMWF: European Centre for Medium-Range Weather Forecasts
ECOP: $\quad$ ECMWF operational

ENSO: $\quad$ El Niño Southern Oscillations

ERA-40: 40-yr ECMWF Re-Analysis

JJA: June-July-August

MAM: March-April-May

NAO: $\quad$ North Atlantic Oscillation

NASA: National Aeronautics and Space Administration

NCEP/DOE: National Centers for Environmental Prediction/Department of Energy

PO.DAAC: Physical Oceanography Distributed Active Archive Center

QuikSCAT: SeaWinds on Quick Scatterometer

RSS: $\quad$ Remote Sensing Systems

SAR: $\quad$ Synthetic Aperture Radar

SLP: $\quad$ Sea-level pressure

SON: $\quad$ September-October-November

SSM/I: $\quad$ Special Sensor Microwave Imager

SST: $\quad$ Sea surface temperature

SWH: $\quad$ Significant wave height

TMI: $\quad$ TRMM Microwave Imager

TRMM: $\quad$ Tropical Rainfall Measuring Mission

VAM: $\quad$ Variational analysis method

WPD: $\quad$ Wind power density.

\section{Competing Interests}

The authors declare that they have no competing interests.

\section{Acknowledgments}

This work was supported by the Junior Fellowships for CAST Advanced Innovation Think-Tank Program "Evaluation of the Oceanic Dynamic Resources of the 21st Century Maritime Silk Road and Its Strategic Points" (no. DXBZKQN-2016-019), the National Basic Research Program of China (Grant no. 2013CB956200), and the National Nature Science Foundation of China (no. 41490642), and the Special Fund for Public Welfare Industry (Meteorology) (Grant no. GYHY201306026). The authors would like to thank Physical Oceanography Distributed Active Archive Center (PO.DAAC) for the help in providing CCMP wind data (available at http://rda.ucar.edu/datasets/ds744.9/).

\section{References}

[1] United Nations Environment Programme (UNEP), "Global trends in renewable energy investment 2015," 2015, http://fsunep-centre.org/sites/default/files/attachments/keyfindings.pdf.

[2] United Nations Environment Programme (UNEP), Global Trends in Renewable Energy Investment 2016, 2016, http://about .newenergyfinance.com/about/press-releases/global-trends-inrenewable-energy-investment-2016/.

[3] D. Carvalho, A. Rocha, M. Gómez-Gesteira, and C. S. Santos, "Offshore wind energy resource simulation forced by different reanalyses: comparison with observed data in the Iberian Peninsula," Applied Energy, vol. 134, pp. 57-64, 2014. 
[4] J. X. Johnson, R. D. Kleine, and G. A. Keoleian, "Assessment of energy storage for transmission-constrained wind," Applied Energy, vol. 124, pp. 377-388, 2014.

[5] Tabassum-Abbasi, M. Premalatha, T. Abbasi, and S. A. Abbasi, "Wind energy: increasing deployment, rising environmental concerns," Renewable and Sustainable Energy Reviews, vol. 31, pp. 270-288, 2014.

[6] M. I. Blanco, "The economics of wind energy," Renewable and Sustainable Energy Reviews, vol. 13, no. 6-7, pp. 1372-1382, 2009.

[7] S. Jung, O. A. Vanli, and S.-D. Kwon, "Wind energy potential assessment considering the uncertainties due to limited data," Applied Energy, vol. 102, pp. 1492-1503, 2013.

[8] R. McKenna, S. Hollnaicher, and W. Fichtner, "Cost-potential curves for onshore wind energy: a high-resolution analysis for Germany," Applied Energy, vol. 115, pp. 103-115, 2014.

[9] NASA, "Global Ocean Wind energy potential," 2008, http:// earthobservatory.nasa.gov/IOTD/view.php?id=8916.

[10] W. T. Liu, W. Q. Tang, and X. S. Xie, "Wind power distribution over the ocean," Geophysical Research Letters, vol. 35, no. 13, 2008.

[11] C. Archer L and M. Z. Jacobson, "Evaluation of global wind power," Journal of Geophysical Research, vol. 110, no. 12, 2005.

[12] BP Company, Energy in 2015: A year of plenty, 2016, http://www .bp.com/content/dam/bp/pdf/energy-economics/statistical-review2016/bp-statistical-review-of-world-energy-2016-spencer-dalepresentation.pdf.

[13] C. W. Zheng and J. Pan, "Assessment of the global ocean wind energy resource," Renewable and Sustainable Energy Reviews, vol. 33, pp. 382-391, 2014.

[14] S. B. Capps and C. S. Zender, "Estimated global ocean wind power potential from QuikSCAT observations, accounting for turbine characteristics and siting," Journal of Geophysical Research Atmospheres, vol. 115, no. 9, 2010.

[15] R. Atlas, R. N. Hoffman, J. Ardizzone et al., "A cross-calibrated, multiplatform ocean surface wind velocity product for meteorological and oceanographic applications," American Meteorological Society, vol. 92, no. 2, pp. 157-174, 2011.

[16] C. W. Zheng, C. Y. Li, J. Pan, M. Y. Liu, and L. L. Xia, "An overview of global ocean wind energy resource evaluations," Renewable and Sustainable Energy Reviews, vol. 53, pp. 12401251, 2016.

[17] C.-W. Zheng, J. Pan, and J.-X. Li, "Assessing the China Sea wind energy and wave energy resources from 1988 to 2009," Ocean Engineering, vol. 65, pp. 39-48, 2013.

[18] C. B. Hasager, M. Badger, A. Peña, X. G. Larsén, and F. Bingöl, "SAR-based wind resource statistics in the Baltic Sea," Remote Sensing, vol. 3, no. 1, pp. 117-144, 2011.

[19] X. T. Chadee and R. M. Clarke, "Large-scale wind energy potential of the Caribbean region using near-surface reanalysis data," Renewable and Sustainable Energy Reviews, vol. 30, pp. 45-58, 2014.

[20] S. B. Capps and C. S. Zender, "Global ocean wind power sensitivity to surface layer stability," Geophysical Research Letters, vol. 36, no. 9, p. L09801, 2009.

[21] I. R. Young, S. Zieger, and A. V. Babanin, "Global trends in wind speed and wave height," Science, vol. 332, no. 6028, pp. 451-455, 2011.

[22] N. Earl, S. Dorling, R. Hewston, and R. Von Glasow, "1980-2010 Variability in U.K. surface wind climate," Journal of Climate, vol. 26, no. 4, pp. 1172-1191, 2013.
[23] B. R. Thomas, E. C. Kent, V. R. Swail, and D. I. Berry, "Trends in ship wind speeds adjusted for observation method and height," International Journal of Climatology, vol. 28, no. 6, pp. 747-763, 2008.

[24] K. Sušelj, A. Sood, and D. Heinemann, "North Sea near-surface wind climate and its relation to the large-scale circulation patterns," Theoretical and Applied Climatology, vol. 99, no. 3-4, pp. 403-419, 2010.

[25] X. Bertin, E. Prouteau, and C. Letetrel, "A significant increase in wave height in the North Atlantic Ocean over the 20th century," Global and Planetary Change, vol. 106, pp. 77-83, 2013.

[26] S. K. Gulev and V. Grigorieva, "Last century changes in ocean wind wave height from global visual wave data," Geophysical Research Letters, vol. 31, no. 24, 2004.

[27] E. R. Cook, R. D. D’Arrigo, and K. R. Briffa, "A reconstruction of the North Atlantic Oscillation using tree-ring chronologies from North America and Europe," Holocene, vol. 8, no. 1, pp. 9-17, 1998.

[28] G. Dodet, X. Bertin, and R. Taborda, "Wave climate variability in the North-East Atlantic Ocean over the last six decades," Ocean Modelling, vol. 31, no. 3-4, pp. 120-131, 2010.

[29] S. K. Gulev and V. Grigorieva, "Variability of the winter wind waves and swell in the North Atlantic and North Pacific as revealed by the voluntary observing ship data," Journal of Climate, vol. 19, no. 21, pp. 5667-5685, 2006.

[30] X. M. Zhai and C. Wunsch, "On the variability of wind power input to the oceans with a focus on the Subpolar North Atlantic," Journal of Climate, vol. 26, no. 11, pp. 3892-3903, 2013.

[31] J. W. Hurrell, "Decadal trends in the North Atlantic Oscillation: regional temperatures and precipitation," Science, vol. 269, no. 5224, pp. 676-679, 1995.

[32] B. G. Reguero, I. J. Losada, and F. J. Méndez, "A global wave power resource and its seasonal, interannual and long-term variability," Applied Energy, vol. 148, pp. 366-380, 2015.

[33] A. Kaplan, M. A. Cane, Y. Kushnir, A. C. Clement, M. B. Blumenthal, and B. Rajagopalan, "Analyses of global sea surface temperature 1856-1991," Journal of Geophysical Research: Oceans, vol. 103, no. 9, pp. 18567-18589, 1998.

[34] C. W. Zheng, J. Pan, and C. Y. Li, "Global oceanic wind speed trends," Ocean \& Coastal Management, vol. 129, pp. 15-24, 2016.

[35] Y. H. Wan, Long-Term Wind Power Variability, National Renewable Energy Laboratory, Golden, Colo, USA, 2012.

[36] W. T. Liu, X. Xie, and P. P. Niiler, "Ocean-atmosphere interaction over Agulhas Extension meanders," Journal of Climate, vol. 20, pp. 5784-5797, 2007. 

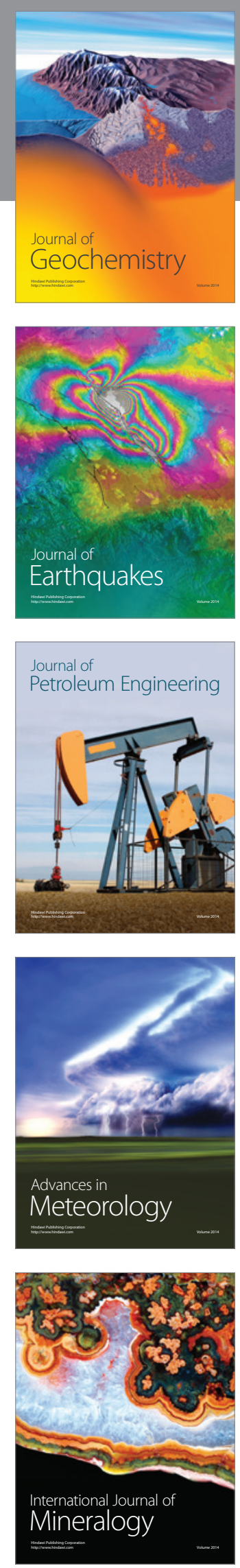
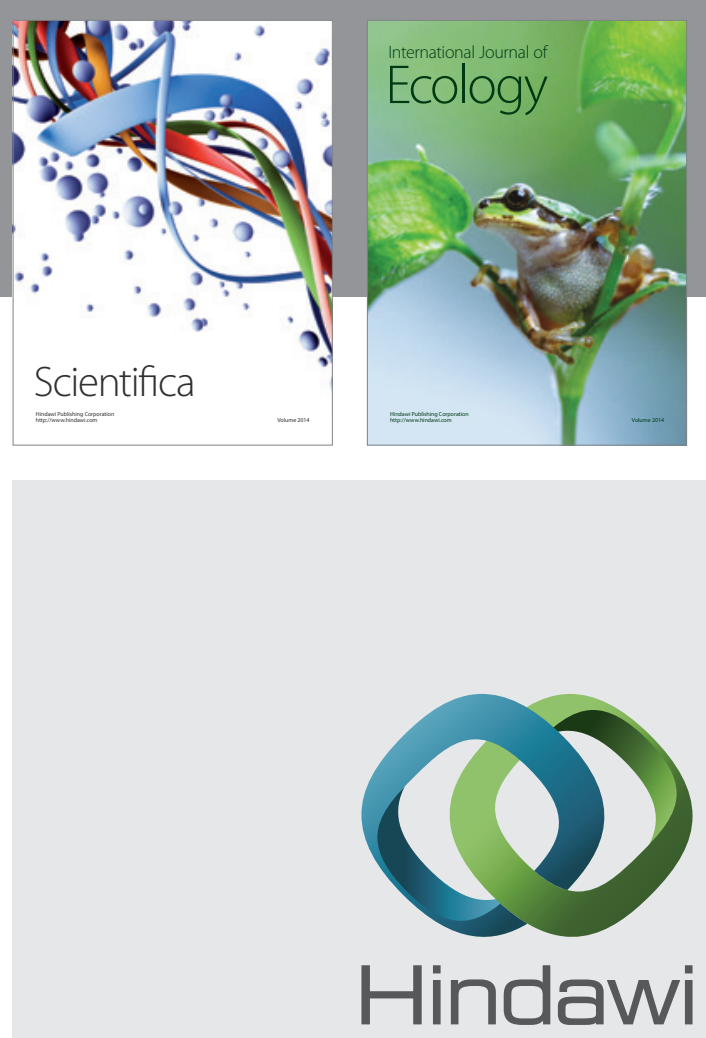

Submit your manuscripts at

https://www.hindawi.com
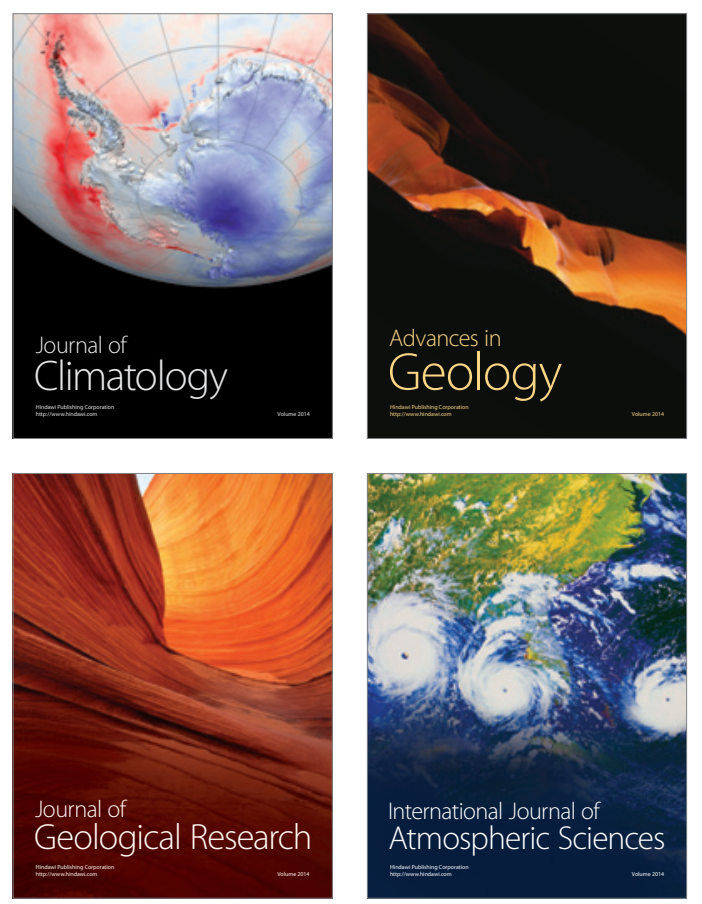

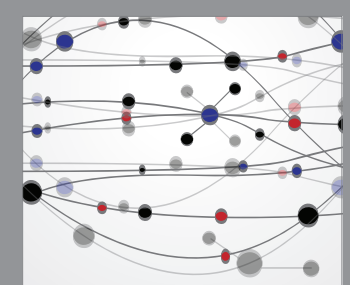

The Scientific

\section{World Journal}
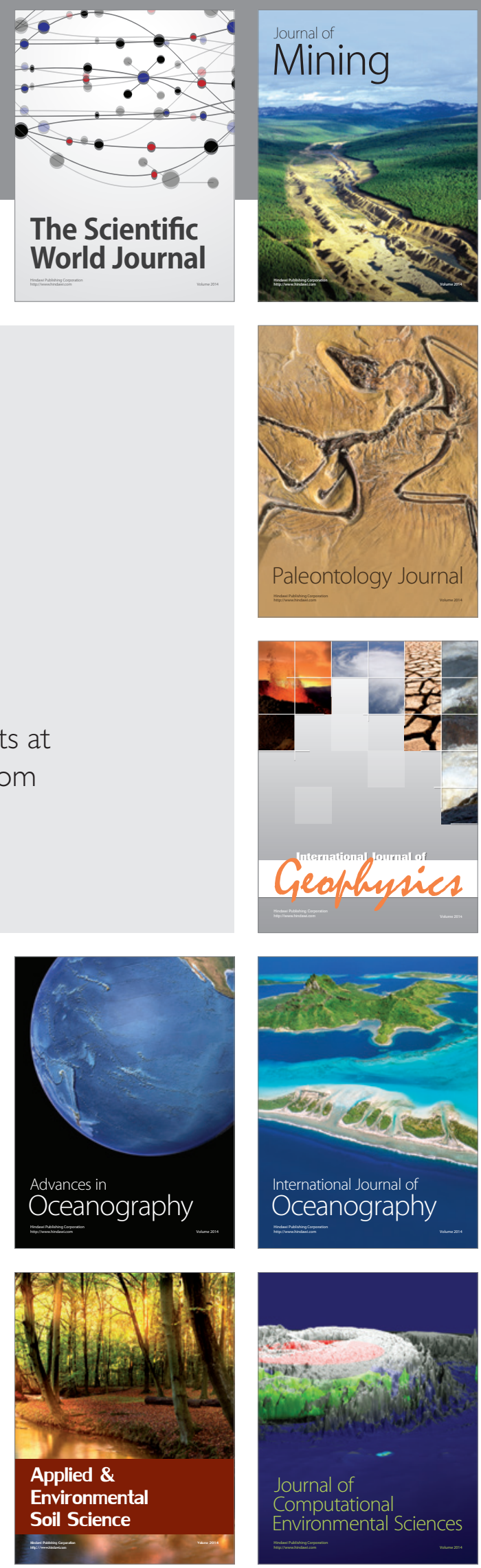